\title{
Suffering and Vengeance in the Psalms
}

\author{
HERRIE F VAN ROOY (NORTH-WEST UNIVERSITY)
}

\begin{abstract}
In the Psalms, the sufferer frequently complains about the suffering he had to endure and asks for deliverance. In some instances, the plea for deliverance includes a cry for vengeance. This contribution examines the issue of suffering and vengeance in the Psalter, giving attention to suffering in the hand of enemies, the terms used, individual and collective suffering, and vengeance. Animosity is a central theme in the Psalter, and through laments, the poet asks for

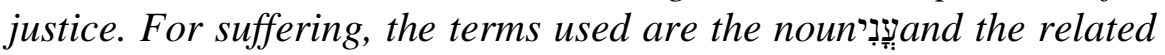
verb III ענה. For vengeance, the verbs נקלם and, גמל and as well as related nouns, are used. Psalms 13,31,37, 91 and 94 are analysed in relation to individual suffering and vengeance and Pss 58, 79, 137 and 149 in relation to collective suffering and vengeance. Vengeance does feature in the Psalms, but very seldom is vengeance asked for as such.
\end{abstract}

KEYWORDS: Suffering, Vengeance, Deliverance, Psalms, Enemies, Wicked, Righteous, Retribution, Laments, Justice

\section{A INTRODUCTION}

Suffering takes many shapes and has many causes in the Psalter. One can hear the agony of the sufferer that is crying out (Ps 22:2), "My God, my God, why have you forsaken me?" These words are uttered by an individual to whom life has almost become too much -words that would reverberate on the cross centuries later. One can sense the pain of the person who is complaining on behalf of his people (Ps 44:23), "Yet for your sake we face death all day long, we are considered as sheep to be slaughtered." These words are quoted by St. Paul in Romans where he lists the threats faced by believers (Rom 8:36). Suffering can be caused by the weight of one's sins, as expressed by the author of Ps 32 in vv.3-4, "When I kept silent, my bones wasted away through my groaning all day long. For day and night your hand was heavy upon me; my strength was sapped by the heat of summer." The poet of Ps 73 suffers when he compares his misfortunes to the happiness of the wicked. In the psalms, the

* Submitted: 05/10/2020; peer-reviewed: 19/11/2020; accepted: 27/11/2020. Herrie F van Rooy, "Suffering and Vengeance," Old Testament Essays 33 no. 3 (2020): 621633. DOI: https://doi.org/10.17159/2312-3621/2020/v33n3a14.

1 The translations in this chapter are from the NIV (electronic ed.; Grand Rapids: Zondervan, 1996). 
poets frequently ask for deliverance from their suffering, for restoration of their fortunes and for God's grace and mercy.

Very often, the suffering of an individual or of the community is caused by the enemies, and results in a cry for deliverance. Psalm 27 is a well-known example of an individual that is praying to be delivered from his enemies, especially as expressed in v. 12, "Do not turn me over to the desire of my foes, for false witnesses rise up against me, breathing violence." In Ps 74:19, the poet asks for deliverance from the enemies on behalf of his people, "Do not hand over the life of your dove to wild beasts; do not forget the lives of your afflicted people forever." However, quite often the plea for deliverance is linked to a cry for vengeance, even for the destruction of the enemies.

In Ps 55:16, the poet asks for the death of his enemies, "Let death take my enemies by surprise, let them go down alive to the grave, for evil find lodging among them." The best-known example of vengeance on the enemies of the people is Ps 137:8-9, "O Daughter of Babylon, doomed to destruction, happy is he who repays you for what you have done to us - he who seizes your infants and dashes them against the rocks."

This article will look at the issue of suffering and vengeance in the Psalter, giving attention to suffering at the hand of enemies, to the terms used and to individual and collective suffering and vengeance.

\section{B ENEMIES IN THE PSALTER}

It is impossible to discuss the notion of enemies in the Psalter exhaustively in this contribution. I have dealt with it to some extent previously, ${ }^{2}$ and will therefore make only a few remarks in this regard. The issue of animosity is no minor theme in the Psalter. It is at the centre of the message of the psalms. ${ }^{3}$ Different kinds of psalms and different poets have different ideas about the enemies. References to enemies occur in a wide variety of psalms, including individual (e.g. 5, 6, 7, 9, 10, 13, 22, 27) and communal (44, 74, 79, 80, 83) laments and the royal psalms. ${ }^{4}$ The enemies of Israel can be identified especially in the royal psalms and the prayers of the community. ${ }^{5}$ This issue is

2 Herrie F. van Rooy, "The Enemies in the Headings of the Psalms: A Comparison of Jewish and Christian Interpretation," in Animosity, the Bible and Us (ed. J. T. Fitzgerald, F. Janse van Rensburg and H. F. van Rooy; GPBS 12; Atlanta: Society of Biblical Literature, 2009), 41-47.

3 Erich Zenger, Ein Gott der Rache? Feindpsalmenverstehen (Freiburg: Herder, 1998), 26.

4 Marvin E. Tate, Psalms 51-100 (WBC 20; Waco, Tex. 1990), 60.

5 Hans-Joachim Kraus, Theologie der Psalmen (3rd ed.; Neukirchen-Vluyn: Neukirchener Verlag, 2003), 156. 
an old problem, described by Mowinckel as early as $1921 .{ }^{6}$ Mowinckel claims that the main question is whether the enemies are external enemies, such as gentiles and foreign rulers, or internal enemies, such as apostate and unfaithful Jews. ${ }^{7}$ He concludes that most scholars recognize both kinds of enemies. Mowinckel further distinguishes between laments of the community and individual laments. In laments of the community, the enemies are external enemies, that is, the enemies of the nation, such as neighbouring countries. ${ }^{8}$ The enemies in the communal laments are generally regarded as foreigners, ${ }^{9}$ while the situation is not that clear with regard to individual laments. Perhaps different options should be kept in mind when one considers the individual laments. ${ }^{10}$

Puukko is of the opinion that in the most instances, the enemies are internal enemies, not foreign enemies; ${ }^{11}$ the enemy is one of the poet's own people. ${ }^{12}$ Birkeland regards the enemies in the individual laments as the same as the enemies in the other groups of psalms, viz. the enemies of the nation, such as the gentiles. ${ }^{13}$ His own view is that there is in principle no difference between individual and collective psalms of lament with regard to the enemies. It is indeed true that individuals have enemies among their own people, but these enemies are usually not mentioned in the psalms. Psalm 127:5 might perhaps be the only exception. ${ }^{14}$ Ridderbos' view differs from both Birkeland and Mowinckel. He says many psalms presuppose a situation similar to that in which David finds himself on more than one occasion, for example, when he is persecuted by Saul, when he endures the revolt of Absalom or when he is opposed by Sheba or Adonijah. ${ }^{15}$ Ridderbos refers to psalms like Pss 3, 5, 7, $11,12,14,17,18,26,28,3,34,40$ and many more. Psalms like Pss 6, 38, 39 and 41 refer to his own people's animosity stirred up by his illness as king or leader. In Pss 10, 12, 14 and 37, the evildoers are Israelites oppressing the helpless, the poor, et cetera. In Pss 20, 21, 33 and 35, the enemies are

6 Sigmund Mowinckel, Awän und die individuellen Klagenpsalmen (vol. 1 of Psalmenstudien; Christiana: Dybwad, 1921), 76.

7 Mowinckel, Awän und die individuellen Klagenpsalmen, 76.

8 Ibid., 76.

9 Cf. Tate, Psalms 51-100, 61.

10 Ibid., 62.

11 A. Filemon Puukko, "Die Feind in den alttestamentlichePsalmen," OtSt 8 (1950):

47-65 (48).

12 Puukko, "Die Feind," 56.

13 Harris Birkeland, The Evildoers in the Book of Psalms (AvhandligerutgittarDet Norske Videnskaps-Akademi I Oslo. Hist.-Filos. Klasse, 1955 no 2; Oslo: Dybwad, 1955), 9.

14 Birkeland, "The Evildoers," 46.

15 Nicolaas H. Ridderbos, Psalm 1-41 (vol. 1 of De Psalmen; KV; Kampen: Kok, 1962), 27. 
foreigners. Brongers agrees that the enemies in the communal laments are foreign enemies. ${ }^{16}$ In these psalms, Pss 44, 74, 79 and 133, among others, the people remonstrate with God about injustices inflicted on them by other nations and petition Him to take action. ${ }^{17}$ In communal laments, the motivation for the psalms is the same in every instance. Foreign armies enter the land of Israel and defeat the people of God. Brongers agrees with the view that it is difficult to identify the enemies in the individual laments. ${ }^{18} \mathrm{He}$ refers to different theories in this regard, including the theories of Mowinckel (sorcerers), Birkeland (national enemies), powers of chaos (the myth and ritual school), Eerdmans (the enemies of the Chasidim) and Puukko (a variety of private and public enemies). ${ }^{19} \mathrm{He}$ states that in the individual laments two kinds of peoples are introduced - people who are ill and people who are unjustly accused. The cry for vengeance belongs to the second group, such as in Pss 5, 7, 9/10, 17, 31, $109,140,141$ and 143.20

The idea that the enemies of the community and the king were foreign enemies has gained almost general acceptance. ${ }^{21}$ In those times, the rule of the king in Jerusalem was regarded as universal, a conviction that was founded in the belief that the universal rule of God was linked to the rule of the king in Jerusalem. Therefore, the nations waging war against the people and its king or rulers were waging war against the people of God and God himself. ${ }^{22}$ The same is true of the enemies in the communal laments. The people's enemies became the enemies of God. ${ }^{23}$ The enemies of the individual were primarily people, but the human picture of the enemy could be transcended such that the enemy would assume the image of evil. ${ }^{24}$ The enemy consisted mainly of the impious and the persecutors of the individual. ${ }^{25}$

Frequently, people would make very negative judgments about the way in which the psalms treat the enemies. To many scholars, the solution to the problem of the enemies is either to ignore or to correct the psalmists'

16 Hendrik A. Brongers, "Die Rache- und FluchpsalmenimAlten Testament," in Studies on Psalms (ed. P. A. H de Boer; OtSt13; Leiden: Brill, 1963), 21.

17 Brongers, "Die Rache- und Fluchpsalmen," 21.

18 Ibid., 27.

19 Ibid., 27-28.

20 Ibid., 28.

21 Cf. e.g. Hans-Joachim Kraus, Psalm 1-59 (vol. 1 of Psalmen; 5th ed.; BKAT 15.1; Neukirchen-Vluyn: NeukirchenerVerlag, 1978), 112; Kraus, Theologie der Psalmen, 157.

22 Kraus, Theologie der Psalmen, 157.

23 Ibid., 159.

24 Kraus, Psalm 1-59, 115-116; Kraus, Theologie der Psalmen, 168.

25 Kraus, Theologie der Psalmen, 161. 
statements about vengeance on their enemies. ${ }^{26}$ Regarding the laments of the individual, some scholars say that these must be seen against the background of a plea for justice. When an individual suffers an injustice at the hands of his enemies, lamentations may be the only means through which he can question the place of justice in the world. The prime concern of the plea in an individual lament is the cry for justice to be done. ${ }^{27}$ The author of a psalm is praying about his suffering because of the acts of injustice done to him. ${ }^{28}$

\section{TERMINOLOGY}

Although the issue of suffering and vengeance occurs quite frequently in the psalms, the words used to denote the two concepts are not frequently found in the psalms. Moreover, they are seldom found together. For suffering, the terms

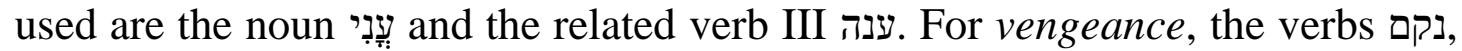
שלם an as well as related nouns are used. There are only seven psalms

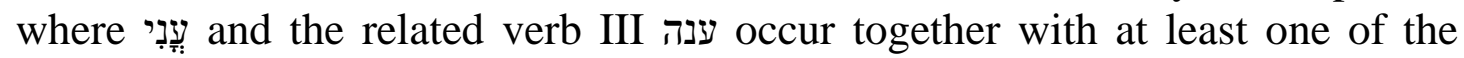
other terms, namely Pss 22, 31, 35, 44, 94, 116 and 119. In these psalms, the words do not necessarily appear in the context of suffering and vengeance. In Ps 22, the poet pleads for deliverance, but vengeance is not mentioned. He says in v. 25 that the Lord has not despised the suffering of the afflicted one, but the verb שלם is used in v. 26 for repaying the vows of the supplicant. Both Psalms 116 and 119 use the different terms in a similar way. Psalm 119 elaborates on the suffering of the poet, but not on vengeance. In Ps 31, the words are also not connected to suffering and vengeance. In Ps. 35, the poet speaks of his enemies who repaid him evil for good. In Ps 44.17 in which the enemies seek vengeance against the poet, he brings his suffering before the Lord in v. 25 .

Psalm 94 is the clearest example in which vengeance and suffering are connected. The psalmist calls the Lord, אל-נְקממות in v. 1, and implores him to appear in his splendour. In v. 2, the poet then asks the Lord to repay the proud for their deeds. The psalm makes it clear that these proud people oppress the people of the Lord and they kill the widows, the orphans and the aliens. Verse 23 states beyond all doubt that the Lord will punish all the evildoers, but without using any of the terms one would expect. The Lord will make their wickedness return to them and destroy them on account of their evil deeds. The poet asks God to avenge him of the people that perform evil deeds against him and his people. The noun is used in the same way as in Pss 94:1 and 18:48.

26 Zenger, Ein Gott der Rache, 43.

27 John W. Rogerson, "The Enemy in the Old Testament," in Understanding Poets and Prophets: Essays in Honour of George Wishart Anderson (ed. A. G. Auld; JSOTSup 152; Sheffield: Sheffield Academic Press, 1993), 289-290.

28 Zenger, Ein Gott der Rache, 133. 
Psalm 137 is probably the psalm that expresses the link between suffering and vengeance in the clearest manner, especially in v. 8, "O Daughter of Babylon, doomed to destruction, happy is he who repays you for what you have done to us - he who seizes your infants and dashes them against the rocks." In this psalm, the poet does not use a word to refer to the suffering of the people, but describes what happened, and then pleads with the Lord to remember what happened and to avenge the people of God. This happens most of the time in the Psalter - the deeds and people who cause the suffering are mentioned, followed by a plea for deliverance and vengeance.

Besides other words are also used to express the suffering of the poet and/or his people. In Ps 13:3, יגוץ is used to denote the agony or grief of the suffering poet (cf. also Pss 116:3 and 31:11). This word is also used to refer to the suffering of the enemies of the people in Ps 107:39.

When one considers the three verbs and related nouns frequently used for repaying the enemies for their deeds, one must remember that these verbs are not always used with God as subject. In Ps 7:5, the verb שלם is used to refer to the deeds of the poet. In Ps 37:21, it is used in the context of repaying debt. In Pss 8:3 and 44:17, the hithpael of נקם denotes the poet's enemies that are bent on revenge. In Ps 99:8, this verb refers to the Lord who punishes the iniquities of his people.

In Ps 13:6, גמל is used for the Lord who vindicates the poet. In this instance, the poet asks to be delivered from his enemies in order to be vindicated, but he does not ask explicitly for vengeance (cf. also Pss 116:7; 119:17; 142:8). In Ps 18:21, גמל is used for the delivery God brought about in the past. In Ps 103:10, the verb is used in a statement that the Lord did not punish his people, as they deserved.

In Ps 31:24, שלםם is used to show that the Lord repays the proud. Again, the poet does not ask for vengeance as such, but declares that the Lord repays those who deserve to be repaid for the evil they did to the poet. In Ps 50:14, the poet encourages people to fulfil their vows to the Lord (cf. also 56:13; 61:9; $65: 2 ; 76: 12 ; 116: 14,18)$. In Ps $62: 13$, the word is used in a general statement to show that the Lord will reward people according to their deeds.

Therefore, one will have to look closely at each instance where these terms are used in order to determine whether a specific instance deals with suffering and vengeance. In the next two sections, the issue of suffering and vengeance will be discussed in a few psalms, as it is impossible to look at all the psalms that are relevant to this issue. 


\section{INDIVIDUAL SUFFERING AND VENGEANCE}

In this section, Pss 13, 31, 37, 91 and 94 will be discussed as representative examples of the suffering and vengeance of an individual. Psalm 94, which explicitly links God to vengeance, will be discussed first.

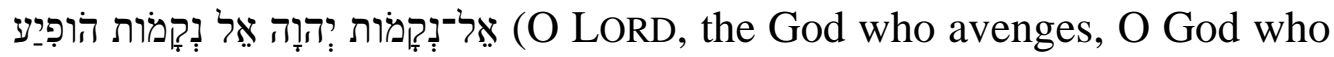
avenges, shine forth).

Structurally, the psalm can be divided into six strophes with three verses in the opening strophe and four in each of the other strophes. Three major sections (1-7, 8-15 and 16-23 $)^{29}$ are distinguished. In the first section, God is called upon to act as judge against the wicked that is oppressing the people of God. The second section addresses first the wicked and then the faithful. The wicked are told that God would judge them and the righteous are told that God would judge but not forsake them. In the next section, the poet talks about how God has delivered him in the past. In the final section, the theme of the psalm is repeated. The poet is sure that God will destroy his enemies. God is called the God of vengeance, the one who exacts vengeance. ${ }^{30} \mathrm{He}$ is the one who will bring judgment when society falls apart. He is the universal judge, who will judge between the righteous and the wicked. In this psalm, the poet does not directly implore God to avenge him. He does not ask for God's vengeance but states the fact that God will wreak vengeance on the wicked. They deserve God's judgment on account of their deeds and the poet is certain that God will bring this about. The same kind of sentiment is expressed in Ps 13. Here the poet talks about his enemies and asks for vindication, but he does not explicitly request judgment on his enemies. He asks how long the Lord will hide his face from him. In this way, he expresses his suffering very clearly, but at the end of the psalm, he rejoices in his faith and trust in the Lord. In psalms like these two, vengeance or judgment on the enemies is taken for granted, not asked for explicitly. In the same vein, Ps 91:8 states that the righteous will see the punishment of the Lord on the wicked.

Psalm 31 is one of the psalms in which the poet expresses his sorrow most clearly, but then in the context of his trust in the Lord. Verse 8 is a good example of this attitude,

(I will be glad and rejoice in your love, for you saw my affliction and knew the anguish of my soul).

29 Cf. Eric Peels, The Vengeance of God: The Meaning of the Root NQM and the Function of the NQM-texts in the Context of Divine Revelation in the Old Testament (OTS 31; Leiden: Brill, 1995), 209.

30 Peels, The Vengeance of God, 209. 
The poet is an innocent person who is suffering. His friends have forsaken him and enemies have risen up against him with slander. He praises God for not having delivered him into the hands of his enemies. This psalm also speaks of the faith and trust of the poet, including the vindication of the poet and the punishment of the enemies, as stated in v. 24, "The LORD preserves the faithful, but the proud he pays back in full." In this remark, the poet, using the verb, שלם, states that the Lord repays those who deserve to be repaid for the evil they have done to the poet.

Psalm 37 is often regarded as being rooted firmly in the wisdom tradition, with retribution and recompense as the central binding themes. ${ }^{31}$ In this context, the poet also deals with the wicked, the evildoers. The wicked will be like grass that withers away very quickly (v. 2). They will be cut off from the land (v. 9). The wicked hatch their plots (v. 12) and attack the poor and needy (v. 14), but their power will be broken (v. 17). In v. 20, the wicked are called God's enemies. They may be prosperous for a while, but they will not endure (vv. 35-36). Sinners will be destroyed, and the Lord will deliver his faithful from the wicked (vv. 38-40). This idea of retribution is well known in wisdom literature and in this psalm, it forms the basis for the Lord's judgment on the enemies of his faithful child.

In the three psalms discussed above, the poet does not ask for vengeance explicitly. He asks for deliverance, knowing the Lord will help him. The salvation he will receive will come through judgment on the enemies. Some scholars regard the psalm as an individual lament and others as an individual thanksgiving. The elements of instruction, prayer and thanksgiving combined in the psalm suggest a liturgical context. A sick person is coming to the temple to request healing. He is surrounded by enemies that formerly were his friends. The psalm consists of a blessing pronounced by a priest (vv. 1-3) and the words of the poet (vv. 4-13). The poet concludes with a prayer for healing (vv. 5-12) and a statement of confidence (v. 13).

The words of the poet in v. 10 must be noted: "But you, O LORD, have mercy on me; raise me up, that I may repay them." The poet is not asking the Lord to avenge him, but he pleads for forgiveness and then calls on the Lord to give him the strength to repay his enemies for what they did to him. Kraus does not think that the poet wants to take personal revenge on his enemies, since the poet is a sick man. ${ }^{32}$ Perhaps, according to Kraus, the Lord will demonstrate by his intervention that these enemies are wicked people, and in this way, they will suffer God's judgment. However, such an interpretation may overlook the

31 Cf. John Eaton, The Psalms: A Historical and Spiritual Commentary with an Introduction and New Translation (CBS; London: T \& T Clark, 2003), 164.

32 Hans-Joachim Kraus, Psalm 1-59 (vol. 1 of Psalmen; BKAT 15.1; Neurkirchen: Neukirchener Verlag, 1960), 314. 
real intent of the poet, who does not only want to be vindicated, but wants to see his enemies suffer for what they have done to him during his time of illness. It seems indeed as though the poet may be seeking to mete out personal revenge in this instance.

In the above examples of individuals suffering and asking for deliverance from their problems, the issue of requesting vengeance is not at the forefront of the poet's mind. Instead, he asks to be delivered, trusts that God will save him and knows that the wicked will be judged in the process. Among the psalms discussed, only Ps. 41 deals explicitly with the issue of vengeance. The next section will deal with the issue of collective suffering and vengeance.

\section{E COLLECTIVE SUFFERING AND VENGEANCE}

For the discussion in this section, four psalms are selected, namely Pss. 58, 79, 137 and 149.

Psalm 79 is often classified as a communal lament or a communal prayer song. ${ }^{33}$ Scholars divide it into different sections, but one can see that the first five verses contain the basic complaint of the poet on behalf of his people, while the rest consists of various petitions. In the first section, the poet describes the situation of the people. Enemies have invaded the land, destroyed the temple and city and killed many people. The result is that the people of God have become an object of scorn. This section concludes with the question of how long the Lord will be angry with his people.

In the next section, the poet asks the Lord to bring judgment on the nations because they have destroyed God's people. He asks for forgiveness as well, knowing that the evil that has befallen the people is the result of their sins (vv. 6-9). Then another question follows in v. 10, linking up with the question of v. 5, "Why should the nations say, 'Where is their God?"” A statement follows, referring to vengeance, "Before our eyes, make known among the nations that you avenge the outpoured blood of your servants." However, in v. 12 , this vengeance is linked to the reproach of the nations against God. Thus, the Lord's vengeance is connected to the glory of his name and to the demonstration of his power. The poet does not ask for vengeance for the suffering of the people per se; rather, he pleads for God's judgment and for the deliverance that only God can bring. When God judges and delivers, the enemy will feel the vengeance of the Lord. There is a connection between deliverance, atonement and retribution in this psalm. ${ }^{34}$ The vengeance is exacted for

33 Cf. Tate, Psalms 51-100, 298.

34 Peels, The Vengeance of God, 213. 
misdeeds committed by the enemies of God's people; vengeance as punishment for evil preserves God's honour. ${ }^{35}$

In Ps 58:11, the issue of vengeance is stated very strongly,

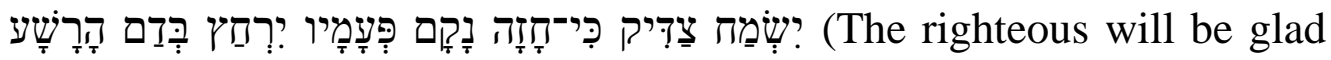
when they are avenged, when they bathe their feet in the blood of the wicked).

Peels calls it one of the most fearful passages in the Old Testament, with its combination of vengeance, joy and feet that are washed in blood. ${ }^{36}$ This psalm is often seen as a communal lament, speaking of corrupt leaders and judges. It remains a question to whom or what the of v. 2 refers. It is frequently emended to אמלים, seen as a reference to (heavenly or earthly) judges. This issue has been much debated. Peels gives a good summary of the different possibilities. ${ }^{37}$ In v. 4 , the focus shifts to the wicked, who are also the object of judgment and vengeance, as expressed further on in the psalm.

The psalm can be divided into four sections, viz. vv. 2-3, 4-6, 7-10 and 11-12. The first section addresses the unjust leaders, the second deals with the nature of the wicked, the third is a prayer for judgment and the final section brings assurance to the righteous. Hossfeldt and Zenger argue that v. 7 is a separate section in the middle of the psalm. ${ }^{38}$ They find a chiastic structure in the psalm, with vv. 2-3 and vv. 11-12 forming an inclusion, and vv. 4-6 balancing vv. 8-10. The psalm wants to elucidate the reversal of the fate of the wicked and the righteous. The wicked are described in vv. 4-6 as being deviant from birth. Verse 7 then asks God to intervene and to destroy the wicked. This is then spelled out in more detail in vv. 8-10, which tells of how the wicked are swept away in God's judgment. Peels says that the curses of vv. 7-10 reflect well known ancient curse formulae. ${ }^{39}$ The destruction of the wicked will bring joy to the righteous - this joy is linked to the avenging of the righteous. The rule of the wicked is broken and this brings about the restoration of justice and the liberation of the righteous. While vengeance is wreaked by God and not by the righteous, justice is likewise delivered by God, says v. 12.

Psalm 149 is part of the concluding Hallel of the Psalter, but it includes a reference to vengeance, something that looks out of place in a song of praise. As it looks into the future, Peels regards Ps 149 as an eschatological psalm. ${ }^{40}$ It

35 Ibid., 214.

36 Ibid., 214.

37 Ibid., 215-217.

38 Frank L. Hossfeldt and Erich Zenger, A Commentary on Psalm 51-100 (vol. 2 of Psalms; Herm.; trans. L. M. Maloney; Minneapolis: Fortress, 2005), 79.

39 Peels, The Vengeance of God, 217.

40 Ibid., 219. 
may perhaps be regarded as an adaptation of a hymnal song of victory. It is not a lament, in which one would expect a plea for vengeance to occur, but a hymn sung to the greatness of God, while looking forward to a judgment to come. This judgment will be carried out by the people of God with a double-edged sword in their hands. In this psalm, it is not the suffering of the people that brings a prayer for judgment to the fore, but the coming of the eschatological kingdom of God, when all his enemies will be destroyed. The people will carry out this judgment as part of the sentence written against the nations, but the reason for the vengeance is not stated in the psalm.

Psalm 137 is probably the psalm most cited in the context of suffering and vengeance. The verb and noun frequently used for vengeance in the Psalter do not occur in this psalm, but the idea is clearly expressed by the use of other terms, especially in v. 8 ,

(O Daughter of Babylon, doomed to destruction, happy is he who repays you for what you have done to us).

This verse, as well as the next one, which describes the dashing of infants against a rock, has evoked very strong negative reactions over time. One of the verbs discussed previously is used in this verse, namely שלם The noun which refers to what the enemies did to God's people, is related to one of the other verbs discussed above. The Babylonians will be punished for their deeds. This is the prayer of the poet.

Among the many terms and phrases that describe this psalm are lament and a song of Zion. The psalm was recently studied by Becking within the context of exile and suffering. ${ }^{41}$ He regards the dichotomy between a God of vengeance and a God of love as obsolete. ${ }^{42}$ Pointing to the cruelty of warfare in the ancient Near East, he states that language comparable to the words in this psalm can be found in inscriptions about the campaigns of the Assyrian and Babylonian kings. ${ }^{43}$ What is awkward about Ps 137 is that it blesses the one who will perform these cruel deeds. ${ }^{44}$ The poet is not going to wreak vengeance in person, but he trusts that the Lord will bring about the punishment of the Babylonians and Edomites. Becking describes this cry for revenge as a more

41 Bob Becking, "Does Exile Equal Suffering? A Fresh Look at Psalm 137," in Exile and Suffering: A Selection of Papers Read at the 50th Anniversary Meeting of the Old Testament Society of South Africa (ed. B. Becking and D. J. Human; OTS 50; Leiden: Brill, 2009), 183-202.

42 Becking, "Does Exile Equal Suffering?" 199.

43 Ibid., 200.

44 Ibid., 200. 
active and concerned way to deal with the alienation experienced by the exiles. $^{45}$

In the four psalms discussed in this section, the issue of vengeance is presented in different ways. In Ps 79, it is linked to the glory of God. The enemies are punished to preserve God's honour. In Ps 58, the suffering of the people will be replaced by joy when God avenges his people. In Ps 149, the vengeance will be brought about by the people as God's instruments, but the vengeance will be an eschatological event. Psalm 137 clarifies the link between the suffering of the people and the request for vengeance. The prayer is that God will bring about retribution, especially for what the Babylonians did to his people when they destroyed Jerusalem and the temple.

\section{F CONCLUSION}

Suffering - both of individuals and of the people - is a common theme in the Psalter. Suffering may be caused by enemies of an individual, but also by enemies of the people. Suffering may also be caused by actions of wicked people, especially in the case of the suffering of individuals. Suffering is in some instances regarded as punishment for the misdeeds of God's people. In some cases, suffering and vengeance can be linked. It is frequently accepted that God will avenge his people for the suffering they had to endure. The prayer of poets to be delivered from the enemies of the people often entailed the destruction of the enemies. In only a few instances, the poet asks for vengeance, especially in the case of the suffering of the people. Vengeance prayed for as such, is quite rare in the Psalter. In this regard, Ps 41 serves as a good example. Ps 137 is the best illustration of a prayer for vengeance by the community.

\section{G BIBLIOGRAPHY}

Becking, Bob "Does Exile Equal Suffering? A Fresh Look at Psalm 137." Pages 183202 in Exile and Suffering: A Selection of Papers Read at the 50th Anniversary Meeting of the Old Testament Society of South Africa. Edited by B. Becking and D. J. Human. OTS 50. Boston: Brill, 2009.

Birkeland, Harris. The Evildoers in the Book of Psalms. AvhandligerutgittarDet Norske Videnskaps-Akademi I Oslo. Hist.-Filos. Klasse, 1955 no 2. Oslo: Dybwad, 1955.

Brongers, Hendrik A. "Die Rache-und Fluchpsalmen im Alten Testament." Pages 21-42 in Studies on Psalms. Edited by P.A.H de Boer. OtSt 13. Leiden: Brill, 1963.

Eaton, John. The Psalms: A Historical and Spiritual Commentary with an Introduction and New Translation. CBS. New York: T \& T Clark, 2003.

45 Ibid., 201. 
Hossfeldt, Frank L. and Erich Zenger. A Commentary on Psalm 51-100. Translated by L. M. Maloney. Minneapolis: Fortress, 2005.

Kraus, Hans-Joachim. Psalm 1-59. BKAT 15.1. Neukirchen-Vluyn: Neukirchener Verlag, 1978.

Kraus, Hans-Joachim. Theologie der Psalmen. 3Ausg. Neukirchen-Vluyn: Neukirchener Verlag, 2003.

Mowinckel, Sigmund. Awän und die individuellen Klagenpsalmen. Psalmenstudien 1. Christiana: Dybwad, 1921.

Peels, Eric. The Vengeance of God: The Meaning of the Root NQM and the Function of the NQM-texts in the Context of Divine Revelation in the Old Testament. OTS 31. Leiden: Brill, 1995.

Puukko, A. Filemon. "Die Feind in den alttestamentlichePsalmen," OtSt8 (1950): 47 65.

Ridderbos, Nicolaas H. Psalm 1-41. De Psalmen 1, KV. Kampen: Kok, 1962.

Rogerson, John W. "The Enemy in the Old Testament," Pages 284-293 in Understanding Poets and Prophets: Essays in Honour of George Wishart Anderson. Edited by A. G. Auld. JSOTSup 152. Sheffield: Sheffield Academic Press, 1993.

Tate, Marvin E. Psalms 51-100. WBC 20. Waco: Word Books, 1990.

Van Rooy, Herrie F. "The Enemies in the Headings of the Psalms: A Comparison of Jewish and Christian Interpretation." Pages 41-58 in Animosity, the Bible and Us. Edited by J. T. Fitzgerald, F. Janse van Rensburg and H. F. van Rooy. GPBS 12. Atlanta: Society of Biblical Literature, 2009.

Zenger, Erich. Ein Gott der Rache? Feindpsalmenverstehen. Freiburg: Herder, 1998.

Herrie F van Rooy, Emeritus Professor, Faculty of Theology, North-West University, Potchefstroom. Email: Herrie.vanrooy@nwu.ac.za. ORCID: https://orcid.org/00000001-5032-2356. 